\title{
The evolution of entrepreneurial competencies: A longitudinal study of university spin-off venture emergence
}

\author{
Einar Rasmussen $^{\mathrm{a}, \mathrm{c}, *}$, Simon Mosey ${ }^{\mathrm{b}}$ and Mike Wright ${ }^{\mathrm{c}, \mathrm{d}, \mathrm{e}}$ \\ ${ }^{a}$ Bodø Graduate School of Business, N-8049 Bodø, Norway \\ ${ }^{b}$ Institute for Enterprise and Innovation, Nottingham University Business School, Jubilee Campus, Nottingham \\ NG8 1BB, UK \\ ${ }^{c}$ Centre for Management Buy-out Research' Nottingham University Business School, Jubilee Campus, \\ Nottingham NG8 1BB, UK \\ ${ }^{d}$ Department of Strategic Management and Business Environment, RSM, Erasmus University, Rotterdam

$$
{ }^{e} \text { EMLyon }
$$

${ }^{*}$ Corresponding author.

Email addresses: einar.rasmussen@hibo.no; simon.mosey@nottingham.ac.uk; mike.wright@nottingham.ac.uk 


\title{
The evolution of entrepreneurial competencies: A longitudinal study of university spin-off venture emergence
}

\begin{abstract}
This paper aims to better understand the development of entrepreneurial competencies to create new ventures within the non-commercial academic environment. We build upon the evolutionary perspective considering where resources come from to help define these competencies and explain their paths of development. The study follows the creation and early growth of four university spin-offs within the UK and Norway. We identified three competencies of opportunity refinement, leveraging, and championing that appeared crucial for the ventures to gain credibility. Although selected competencies were inherent within the academic founders, the specific competencies for venture creation had to be developed or acquired. This was achieved iteratively through entrepreneurial experience and accessing competencies from disparate actors such as industry partners and equity investors.

Propositions are offered to guide future empirical research based upon our framework. Keywords: Academic entrepreneurship, entrepreneurial competencies, opportunity, resource acquisition, university spin-off ventures
\end{abstract}




\section{The evolution of entrepreneurial competencies: A longitudinal study of university spin-off venture emergence}

\section{INTRODUCTION}

Understanding how new ventures emerge is a major research challenge, and a better explanation of how entrepreneurial ventures are created and developed is warranted (Alvarez and Barney, 2007). The entrepreneurial process is inherently complex due to uncertainty regarding how best to develop a business concept (Bhave, 1994), acquire necessary resources (Baker and Nelson, 2005), and make effective decisions (Sarasvathy, 2001). Thus, the nascent venture needs a broad set of different competencies to be able to proceed from an idea to a value creating firm.

For most nascent ventures these competencies are not readily available, but have to be developed or acquired during the early phases of their development. These initial phases concerning the processes of venture development, or organizational emergence (Lichtenstein et al., 2006), have been largely neglected (Davidsson and Honig, 2003). Understanding these processes is important since findings regarding the development of competencies and capabilities based on established firms may not be transferable to new firms (Zahra et al., 2006). We investigate the specific competencies required to overcome the initial hurdles of the venture creation process in order to gain credibility with potential investors and partners and how these competencies are accessed.

In the literature, terms such as competencies, capabilities, resources, assets, and skills are often used interchangeably (Colombo and Grilli, 2005). In this paper we focus on competencies and follow the definition of Danneels (2002, p. 1102) that a competency is an 'ability to accomplish something by using a set of material and immaterial resources'. A competency focus therefore necessitates consideration of the human aspects of the entrepreneurial process. Adopting an evolutionary perspective, we suggest that spin-offs develop competencies over time along a development or search path that is partly influenced by their starting environment but which also requires a departure from existing trajectories (Ahuja and Katila, 2004).

To address these issues, therefore, we consider a specific context of entrepreneurial activity (Kuratko et al., 2005). We focus our investigation on the creation of spin-off firms by 
university researchers based on academic research. These firms provide a novel context in which to begin to fill the research gap regarding organizational emergence in different institutional settings (Sapienza et al., 2004; Shane and Stuart, 2002). Due to the early stage and embryonic nature of university technologies (Agrawal, 2006), the high knowledge content, and the many actors involved, these spin-off firms typically face substantial hurdles that make them well suited to reveal how competency deficiencies are overcome. Moreover, the context is distinct as university spin-offs usually involve the development of a business opportunity based on novel and potentially disruptive technology or tacit knowledge emerging from academic research (Ardichvili et al., 2003; Markman et al., 2008). Godfrey and Gregerson (1999) propose that a focus upon the emergence of such technologies should provide new insights into the process of competence evolution. The university context arguably provides an ideal setting to observe the birth of potential high technology firms. By observing their genesis and early development, insights into how such firms can gain an idiosyncratic resource base to provide credibility within typically fast moving markets can be gained (Eisenhardt and Brown, 1998).

Despite being likely environments for high-technology firm creation, paradoxically universities are generally ill-suited to develop new ventures due to potential conflicts of interest with their traditional roles of research and teaching (Ambos et al., 2008; Shane, 2004). As a result, university spin-off ventures that attempt to develop by deepening existing path dependencies will likely encounter significant barriers to competence evolution. Ambos et al. (2008) propose that academic entrepreneurs need to be ambidextrous to deal with the tensions between academic and commercial outputs. Academic spin-off ventures therefore require the creation of new development paths that depart from existing practices in the academic context.

Although many studies have examined the university spin-off formation process (Mustar et al., 2006), there is a gap in the literature relating to which competencies are necessary, who provides them and how they are developed. This presents a methodological challenge as it typically takes many years from the initial emergence of the business concept until the economic potential is proven in terms of market acceptance. Therefore, understanding of which competencies are necessary to create a new venture is typically deduced retrospectively. We resolve this challenge by investigating the process longitudinally and by observing firms transcending the initial phases of venture development, arguably the most 
influential in terms of the path upon which the venture evolves (Clarysse and Moray, 2004; Lounsbury and Glynn, 2001). In this way we can observe the competencies required to make the transition from academic research to the development of a potential commercial opportunity and how they evolve.

An important threshold for nascent ventures is to gain sufficient credibility to access and acquire key resources such as financing and human capital to form the entrepreneurial team. In line with Vohora et al., (2004, p. 164) we define overcoming the credibility threshold to involve the 'ability to gain access to and acquire an initial stock of resources, which are required for the business to begin to function'. We use two proxies to identify when the nascent venture passes the credibility threshold. Following Vohora et al. (2004), a credible venture needs a competent entrepreneurial team, which for university spin offs usually requires adding new team members beyond the original inventor(s). In addition, we propose that an early stage investment from a private sector investor with no formal connection to the entrepreneurial team is an indicator that the nascent venture has reached the credibility threshold (Lockett and Wright, 2005). Thus, in this study we pose the following research question: Which entrepreneurial competencies are needed for nascent spin-off ventures within a university context to reach the credibility threshold; Who provides these competencies? and: How are these competencies developed?

We make several contributions to understanding the initial development phase of new ventures. In particular, we address the research gap regarding new venture emergence in different institutional settings by extending analysis of the role of incubator organizations to the traditionally non-commercial university context. We propose that two factors are particularly distinctive for university spin offs; the heterogeneous features of entrepreneurial competencies and the diversity of who provides them. Hence, we contribute by showing that it is not sufficient to state that certain competencies are needed but that it is also necessary to identify who provides them and how they evolve. First, we argue an opportunity refinement competency is needed to discover opportunities based on scientific research and to further refine these opportunities into viable business concepts. For this competency, career academic entrepreneurs appear distinctive in needing to evolve the ability to attract new team members with industrial experience who can identify and interact with industrial partners. Second, a leveraging competency is needed to develop and integrate the internal and external resources necessary to nurture the new spin-off venture. For this competency, career academic 
entrepreneurs need to evolve their credibility and entrepreneurial experience to enable interaction of the entrepreneurial team with external resource providers and here the parent university organization, the university TTO, and public support schemes can assist the entrepreneurial team. Third, a championing competency is needed to identify with the venture and to convince others to contribute to its development. For this competency, there is a distinctive need to evolve the championing competency from the entrepreneurial team and the internal university context to also include champions within external resource providers.

By analyzing the evolution of competencies in an academic entrepreneurship context, we contribute to the somewhat limited literature relating to where resources to build new ventures come from. Specifically, we show how the evolution of these competencies depends on the starting configuration and context of the nascent venture. We make a novel contribution by showing that rather than being homogeneous, the three competencies of opportunity refinement, leveraging, and championing follow different development paths and that contributions from different actors are needed to build each competency. This study provides a novel approach to unravel the specific path by which each competency is built over the initial phases of venture emergence. As such, we contribute to emerging literature that seeks to understand how and when firms create new development paths that depart from existing path dependencies.

By focusing on competencies, rather than actors at several levels of analysis, we contribute to reducing the research gap regarding multi-level entrepreneurship research (Alvarez and Busenitz, 2001). This helps identify the contribution of different actors to building and supporting the development of spin-off firms. These insights can inform policy makers, university administrators, educators, and support agencies about how to target their efforts to increase the number and success of spin-off ventures. Finally, by selecting cases in different countries, universities, and industry sectors, we obtain variation in both the external environment and the institutional context and thereby enhance the external validity of the study.

This article proceeds as follows. Section 2 presents our theoretical framework which builds on the evolutionary literature on resource development to analyze the competencies needed for venture creation and early development. The third section presents the methodological approach used for the longitudinal study of four university spin-off processes. In the fourth 
section, the empirical findings are presented in conjunction with our analysis and propositions are derived. Finally, a discussion considering the implications for further research and practice is provided.

\section{THEORETICAL FRAMEWORK}

To investigate this area we utilise an evolutionary perspective on the acquisition of competencies and build a theoretical framework through integrating prior empirical work on the emergence of high-technology ventures, the influence of the incubator environment, and academic entrepreneurship. Following Conner (1991) and Ahuja and Katila (2004) we address a key gap in the literature concerning where resources come from. The answer to this question is particularly relevant within high-technology ventures as the generation and exploitation of idiosyncratic resource bundles provides, at best, only a temporary competitive advantage within typically fast moving markets. Godfrey and Gregerson (1999, p41) argue that to sustain a competitive advantage in this turbulent environment requires 'an entrepreneurial ability to identify, develop and complete new combinations of existing asset bundles or new unmet opportunities.' This builds upon the work of Penrose (1959), who argues that entrepreneurial ability should be considered separately and distinctly from other resources.

Prior work on entrepreneurial competencies has focused on the individual entrepreneur (Chandler and Hanks, 1994; Man et al., 2002). Yet, for high-technology firms, it is unlikely that one individual entrepreneur possesses all the competencies necessary to gain credibility for the new venture. Consequently, high-technology new ventures are often developed by teams (Roberts, 1991) and studies of university spin-off projects have shown them to be characterized by a dynamic interaction of different individuals with different competencies throughout the start-up process (Clarysse and Moray, 2004; Vanaelst et al., 2006).

Rather than focus upon competencies, prior studies have used the broader lens of resources. These can be defined as the multifarious input factors needed to create a new venture (Zott and Huy, 2007). It has been shown that tangible resources, such as access to financial and human capital, are crucial for the entrepreneurship process (Cooper et al., 1994). In a longitudinal study of the evolution of resources, Lichtenstein \& Brush (2001) identified both tangible resources (technology, organizational infrastructure, and organizational planning) and intangible resources (employees, knowledge/expertise, reputation, culture/identity, 
relationships/alliances, sales and service delivery, business base, and decision making) to be necessary. They concluded that intangible 'soft' resources are more useful than tangible resources in the early stage of venture development. Moreover, studies have shown how informal networking (Khavul et al., 1998), the building of legitimacy (Zimmerman and Zeitz, 2002), and the utilisation of symbolic management can be used to acquire resources (Zott and Huy, 2007).

Yet new venture creation does not occur in a vacuum. It is path dependent. A long research tradition has demonstrated that the institutional incubator environment influences the nature of the development of new entrepreneurial ventures through providing (or inhibiting) access to resources (Gnyawali and Fogel, 1994; Mustar et al., 2006; Phan et al., 2005). Potential incubator organizations include industrial corporations, science parks, and universities. Studies of corporate spin-offs show that their development (Klepper and Sleeper, 2005) and growth (Sapienza et al., 2004) is influenced by the resources inherited from the parent incubator organization, and that the degree of overlap of knowledge between the parent and the spin-off is especially important. Similarly, science parks can provide general management experience to assist new venture development in the firms located therein (Westhead and Storey, 1995), but this varies between different types of science park. The extent to which an incubator is embedded in an entrepreneurial system also facilitates new venture development (Neck et al., 2004).

Universities provide a distinct institutional incubator environment that likely influences the evolutionary path of competence development. While the identification and resolution of knowledge gaps are the central concern of universities, the types of knowledge gaps a university deals with are likely qualitatively different from those faced by emerging business ventures emanating through corporate entrepreneurship. Studies have shown that spin-off formation can be significantly constrained by organizational and cultural barriers (Lee, 1996). The academic entrepreneurship process may be inhibited by a lack of business experience and commercial skills among academics (Vohora et al., 2004). This is compounded by possible conflicts of interest with other university tasks such as research and teaching (Mustar et al., 2006). Consequently, the creation of spin-offs typically lacks consistent support at school level despite support by central administration. It is often argued that the pursuit of private gain is incompatible with academic values relating to scholarly freedom and can undermine the creation and dissemination of knowledge and the education of students (Shane, 2004). 
Universities can be an important resource provider for spin-off ventures (Smilor et al., 1990), but universities may also have resource deficiencies and competency deficiencies that inhibit the new venture incubation process (Clarysse et al., 2005).

The literature on academic entrepreneurship has identified specific resources and capabilities associated with spin-off firm formation, such as intellectual human capital (Zucker et al., 1998), technological resources (Heirman and Clarysse, 2004), university level characteristics (Di Gregorio and Shane, 2003; Jong, 2006) and routines (Lockett and Wright, 2005). These studies have provided classifications or lists of resources and capabilities that likely foster spin-off creation and development. However, entrepreneurial opportunities are heterogeneous and as such may require unique sets of resources to be exploited. As a result, researchers have encountered difficulty in specifying a set of resources leading to superior start-up performance. We argue that the venturing process is not dependent on a specific set of resources, but on the ability to use combinations of both tangible and intangible resources. Thus, a set of competencies may be needed to gain credibility for the fledgling venture. For instance, the problem of a lack of resources facing a new venture can be overcome if the competency to acquire the relevant resources is available.

Building upon the need for further understanding of entrepreneurial activity in existing institutional settings, Hayton and Kelley (2006) propose that four entrepreneurial competencies, or roles, are necessary in the context of corporate entrepreneurship: innovating (opportunity recognition and further exploitation of the opportunities), brokering (accessing and combining new sources of knowledge and information), championing (identifying with the opportunity and taking responsibility to move it forward), sponsoring (help in gaining access to the resources needed). Although universities present an existing institutional setting that is distinct from commercial corporate settings (Ambos et al., 2008), we propose that analogous competency gaps are plausible. Corporate spin-offs are concerned with building legitimacy for new products, services or ways of working within a context that is typically resistant to such changes (Sapienza et al., 2004). Similarly, university spin-offs are concerned with building legitimacy for commercial endeavours that are not the central concern of the parent organisation (Vanaelst et al., 2006). This argument is supported by studies that have observed corporate spin-off venture performance being constrained by a lack of competence (Sapienza et al., 2004) or that have proposed a link between specific competencies within academic ventures and venture performance (Shane and Stuart, 2002). Yet universities are 
distinct in that they traditionally operate in a non-commercial context. The development of university spin-offs thus represents an idiosyncratic situation where the use of pre-existing capabilities may be limited and new development paths may need to be created (Ahuja and Katila, 2004). As a result, we may expect to see critical differences in how resources are acquired between the corporate and university contexts.

Considering Hayton and Kelly’s (2006) proposal for the need for an innovating competency, academics may be skilled at innovating within the research domain yet this may be of little use in identifying opportunities within the commercial context (Lockett et al., 2003). Here, prior industrial experience may provide an enabler to allow academics to position their research within the commercial arena (Almeida and Kogut, 1999). However, regardless of the potential commercial viability of academic research, universities may represent an environment where the ability to develop relationships with external actors, such as potential industry partners, may be problematic (Kenney and Goe, 2004). To address the perceived barrier between academe and industry, actors may perform a brokering role, analogous to that suggested by Hayton and Kelly (2006) in the corporate context. For instance, universities have introduced technology transfer offices (TTOs) designed to help build strong ties to industry partners for collaborative research and the development of joint ventures to exploit university research. Despite the proliferation of TTOs, some authors have questioned their efficiency due, in part, to a lack of entrepreneurial and industry experience (Clarysse et al., 2005).

As an alternative to TTOs acting as brokers, Franklin et al. (2001) have suggested that experienced surrogate entrepreneurs should be used in a more direct role as champions or sponsors of nascent academic ventures thereby providing the remaining competencies suggested by Hayton and Kelly (2006). The use of experienced entrepreneurs is proposed to provide access to potential investors and potential customers via strong ties built through prior venture ownership experience. More experienced academic colleagues may also contribute in a sponsoring role. Studies have shown that academic colleagues with entrepreneurial experience can assist their colleagues at different stages of venture creation (Mosey and Wright, 2007).

Within academic entrepreneurship, development of entrepreneurial competencies within the firms and the acquisition of competencies external to the firm may, therefore, have a positive 
effect on commercialization success (Zahra and Nielsen, 2002). However, the creation of these competencies and the temporal role of multiple actors and how their relationships evolve in the early stages of venture development is missing in our understanding of entrepreneurial competencies. Although the concept of competencies appears promising to better understand academic entrepreneurship, we propose an in-depth investigation of the start-up process is necessary in order to build a more inclusive theoretical framework (Man et al., 2002).

\section{METHODOLOGY}

\section{Research design}

To examine the entrepreneurial competencies needed, a longitudinal multiple case study approach was chosen, guided by the conceptual framework outlined above (Godfrey and Gregerson, 1999; Suddaby, 2006). This approach gives a richer contextual insight and an indepth understanding of processes that have been neglected in prior studies (Rothaermel et al., 2007). From the literature reviewed above, it seems clear that different competencies are used at different times in the spin-off process and the actors providing these competencies also change over time. Thus, a longitudinal approach is warranted to capture the changes over time and reduce problems of retrospective biases (Pettigrew, 1990). Moreover, the use of comparative case studies is appropriate to gain insight into such dynamic organizational phenomena (Eisenhardt, 1989).

\section{Case selection}

The creation of new ventures is dependent on the environment (Gnyawali and Fogel, 1994) and the institutional setting (Dobrev and Barnett, 2005) where the process is enacted. Organizational structure may facilitate or inhibit entrepreneurial activity (Burgelman, 1983), and cultural factors play a role in new venture formation within the university context (Kenney and Goe, 2004). To enhance the external validity and identify competencies that transcend significant contextual variation, we adopted theoretical sampling (Eisenhardt, 1989) and selected cases within different national, university, and industry/ market contexts (Yin, 1989). First, we selected cases from the UK and Norway which represent distinct institutional contexts. In the UK, commercialization of research has been high on the agenda since the 1990s and an infrastructure of TTOs is well established at most universities. British universities have been highly active in spin-off creation compared to other countries (Wright et al., 2007). In contrast, Norwegian universities have only recently become formally involved 
in spin-off formation. While previously belonging to the individual academic, IP ownership of academic research was only more recently assigned to universities from 2003. This led to the establishment of TTOs at Norwegian universities, increased awareness within the institutions, and increased public spending to facilitate commercialization of research. Second, in each country we chose one university with a relatively well developed institutional infrastructure for technology transfer and spin-off venture formation and one university with a less comprehensive commercialization support tradition, as the existence of support infrastructure may impact upon the acquisition of competencies (Ambos et al., 2008). Descriptive characteristics of the universities we selected are provided in Table I.

\section{INSERT TABLE I HERE}

Third, to capture different environmental contexts related to market and industry environment we included cases from two contrasting research disciplines; biological sciences and engineering. These disciplines represent the two major industries where spin-offs occur (Shane, 2004), however there might be differences in the need for resources (Druilhe and Garnsey, 2004) and the nature of social capital (Mosey and Wright, 2007) between these disciplines. This might be due to differences in the type of business activity or 'business model' typically employed by these firms (Druilhe and Garnsey, 2004). Finally, we selected cases where the spin-off was developed on the basis of a technology emerging from university research and where the initial entrepreneurial team included at least one academic researcher. Because we searched for projects in the early stage of development, with an incomplete entrepreneurial team and no external investors, prospective cases had to be identified through visits and discussions with contacts at each university. At the time of our study, we identified only a small number of cases that suited our criteria. After an initial contact with each case, where we presented our research objectives, we selected the cases where we managed to negotiate good access to collect information about their development process. Table II provides descriptive characteristics of the resulting four spin-off cases in the study.

\section{INSERT TABLE II HERE}

\section{Data collection}

Data triangulation was incorporated by including several sources of data to map the situation and capture critical events prior to and during the development of the four spin-off projects. 
Secondary data from the universities was collected through documentary sources such as strategy plans, annual reports, and web pages. Primary data from each university was collected through visits, conversations, and interviews. Primary data from the spin-off projects was collected by face-to-face interviews with the company founders conducted at regular intervals throughout a 12-18 month period from spring 2004. For each round of interviews we typically returned to the company founders to get an updated account of the development of the start-up process. In addition we identified and interviewed other individuals involved in the process to provide alternative perspectives. Interviewees included all company founders and members of the entrepreneurial teams, selected board members, university managers, people involved in commercialization support, and other relevant individuals. We made four rounds of interviews in cases Alpha and Gamma, and three rounds in cases Beta and Delta. The decision of who to interview in each round were informed by ongoing analysis and aimed to gain additional perspectives on existing data as well as an update on recent events in each case. Table III shows the respondent role and the number of interviews with each person.

\section{INSERT TABLE III HERE}

The data collection ended when each firm had reached the credibility threshold and additional interviews mainly confirmed, rather than supplemented, our existing data regarding the venturing process. A total of 54 interviews were conducted and each interview typically lasted between 45 and 90 minutes. Interviews were recorded and transcribed by the authors as part of the data analysis process. Following a narrative approach (Polkinghorne, 1988), the interviewee was asked to describe his or her involvement in and knowledge of the spin-off project from its inception to date, with a minimum of interruption by the interviewer. Most interviewees openly described their actions and the key events of the start-up process in a chronological order. The use of narrative interviewing (Czarniawska, 1998, p. 29) enabled us to get closer to the actual events and to avoid personal views and theoretical perspectives influencing the data collection. To gain more detailed information concerning the critical events and the actors involved as the start-up process progressed, we used open follow-up questions such as: "Why did you do that?" "Who was involved in this event?" "Did you consider alternative actions?" "When did this happen?” To avoid biases, the concepts of resources and competencies were not explicitly referred to by the interviewers. 
Typically, archival data regarding the pre start-up and start-up activities of nascent ventures are scarce. Nevertheless, we were able to obtain information such as company presentations, financial reports, business plans, market analyses, and research documents from all cases. In addition, relevant written documentation was collected both from the interviewees and other sources such as magazines, newspapers, and the internet. By combining the different sources of information and by collecting information over a period of time through repeated interviews with central people, an in-depth description of the research and commercialization process was obtained. For confidentiality reasons the cases are anonymized.

\section{Data analysis}

From the data we identified critical characteristics and events that influenced how the spin-off venture emerged and developed. The interview transcripts and other material were read and reread as data were collected; emerging themes were refined as this process progressed and checked through the repeat interviews with the main players (Yin, 1989). The views of the different respondents from each case were also compared by representing the entire start-up process of each firm in tabular form and as a narrative text.

To derive theoretical explanations for the processes observed, we identified observations that matched theoretical concepts (Orton, 1997). The data analysis focused on how different types of competencies were used to develop the nascent spin-off ventures and the sources of these competencies. To avoid conflating the multiple levels of analysis, the strategy of retroduction was used (Downward and Mearman, 2007; Leca and Naccache, 2006). Thus, as the analysis proceeded, the overarching logical frame shifted from exploring data, to building theoretical models, and empirically scrutinizing these models (Van de Ven and Poole, 2002). In order to avoid confirmatory biases, one of the authors did not participate in data collection.

The data analysis is presented in two-ordered steps (Taylor and Bodgan, 1984). Initially, a first-order analysis of the development within each case revealed three main categories of competencies. In Table IV, we summarize our findings for each case structured by each competency. This was followed by a second-order analysis used to develop propositions through analytical generalization (Yin, 1989), guided by the extant theory previously discussed. 


\section{FINDINGS}

The purpose of this study was to develop an understanding of new venture emergence in the university context by revealing the acquisition and development of the entrepreneurial competencies used for the new ventures to reach the credibility threshold. The findings presented below are an integration of our case studies and the scholarly literature.

\section{Achieving the credibility threshold: categories of entrepreneurial competencies}

Despite the unique technologies and markets and the different national, university, and market/ industry environments exhibited by the four cases, each eventually reached the credibility threshold (Vohora et al., 2004). The credibility threshold was defined as both the establishment of an entrepreneurial team and achieving external private sector finance in order to sustain the venture development (see Table II).

Case Alpha was initiated by four university professors, but an experienced entrepreneur and a business lawyer were soon added to the start-up team. Alpha gained some initial funding from public sources, but within one year was able to leverage development grants from two industry partners that saw potential benefit in the business opportunity. After a period of prototype development and successful pilot trials, one of the industrial partners provided substantial equity finance.

Beta was established by two university professors. Initially they were dependent on public funds, but soon needed private investment to sustain their development. The first round of equity finance was obtained through issuing a small private offering. This funding enabled an expansion of the entrepreneurial team by attracting professional business developers and board members. Subsequently, new rounds of private placements were issued to sustain the venture development.

Gamma was initiated by a senior lecturer who recruited a post doctoral researcher with industry experience to develop the concept and gain seed funding from public sources. Through a local networking event, the inventor met an experienced entrepreneur who joined the team and recruited a finance and marketing director. Together they wrote a business plan for the nascent venture and pitched the idea to a venture capital firm who subsequently invested in the, now credible, team. 
Delta arose from the research of two professors who gained a small public grant to develop the concept and recruit a post doctoral researcher. The researcher developed a business plan and began collaborating with an industry partner to develop a working prototype.

Subsequently the industry partner became an equity investor and development partner for a new generation of products utilizing their technology.

When we analyzed our case material, the concept of competencies emerged as crucial for gaining credibility for the nascent ventures. Without exception, the actors involved acknowledged that certain competencies were needed to articulate the latent value within the emerging venture to potential investors. For instance, an advisor involved in the Beta case explained: 'It is difficult to know how to commercialize an idea; to sell 'air' is difficult, so you need competency. [...] I think many commercialization projects fail because a lack of competency.' (O1 - see Table 4) ${ }^{1}$. Further, the Alpha founders were very conscious of the competencies needed, as one said: 'I believe we have been able to put together a team which has the critical competencies needed to run the further company development.' (F1)

As our research progressed, we identified three entrepreneurial competencies that were important for the nascent ventures to gain credibility. The first competency we identified related to the discovery or enactment of an opportunity and the ability to further refine and develop the opportunity into a clearly articulated and commercially viable business concept. Thus, we propose that an opportunity refinement competency is of crucial importance to develop the new venture credibility. The second competency we identified related to the development and acquisition of resources to build the new venture. Thus, we propose that the spin-offs are dependent on a leveraging competency to sustain their development. In contrast to the corporate entrepreneurship context analysed by Hayton and Kelley (2006), we were not able to make a distinction between the brokering and sponsoring competencies. The final competency we identified related to the personal commitment or the leadership role needed to sustain the venture start-up process. Thus, we propose that a championing competency is critical for a new venture to emerge.

A summary of the empirical data from each case relating to each competency, including quotes from the interviews, is provided in Table IV.

\footnotetext{
${ }^{1}$ The quotes from case Alpha and Beta are translated from Norwegian. We chose the direct translation of Norwegian "kompetanse" to "competency", but an alternative translation could be "expertise".
} 


\section{INSERT TABLE IV HERE}

\section{Development of propositions}

In the next sub-sections we present the three competencies and how they contributed to help the four cases develop credible ventures. We derive propositions related to the evolution of each competency.

Opportunity refinement competency. University spin-offs are usually based on ideas with high knowledge content and technologies that are radical in nature. The Alpha case was based on many years of engineering research, Beta was based on the discovery of a medical effect, Gamma was based on research into fluid flow measurement, and Delta was based on an energy saving technology. Although academic research was a necessary condition for the business opportunity to be created, it was not sufficient for the new venture process to start. Here they had to acquire and develop some form of market related competency to initially frame the business idea. Table IV illustrates the evolution of competence development, as the individuals started with limited skills but then added what was missing to enable the opportunity to be refined. This was observed most evidently at Delta where the academic founders were finding it difficult to understand the market value of their research. As career academics, they lacked the ability to interact with the market in order to position their work relative to commercially available technologies. They needed to access this ability and recruited a researcher specifically for this task, who had prior industry experience. The researcher explained how he used external actors known to him from his industrial career to gain valuable market knowledge:

'They (Founders 1 and 2) were just sitting in the lab wondering who to talk to about it, but scared to death of giving away their secret. I just rang people up and asked what they were looking for. It soon became clear that they were being squeezed for lower and lower running costs and that was where our kit really offered an edge. So we spoke to the TTO and started to think about how to explain how good it was without explaining how it worked.'

Thus, an evolution towards greater industry experience internally in the entrepreneurial team was important to be able to frame and revise the scientific knowledge into a viable business opportunity. This was also readily apparent at Alpha and Beta where prior industrial 
experience amongst the academic founders helped them to understand the potential commercial viability of their research. This also helped them to interact with external actors to refine the opportunity further. In all cases the nascent ventures became increasingly dependent on using the competency of external market actors such as industry partners and prospective customers to sustain the development of the opportunity. A consistent picture was of an evolution from university researchers playing a very important role in the earliest stages of this process, with their interaction with other actors becoming more important in the later stages (Table IV). Thus, it was important to continue to engage the inventor(s) to achieve commercialization success (Agrawal, 2006). This iterative, 'trial and error' process where the original idea was refined through market actors responding to a series of revised concepts, was succinctly described by one of Gamma's founders:

'It was so frustrating, each medic we spoke to gave us another hurdle to jump over that we had no idea was there. We went away, jumped over it and then came back with positive results only to find another hurdle, another type of test or whatever. It was such a rollercoaster.'

In all our cases the initial idea had to be refined several times before gaining external credibility. Thus, the opportunity refinement competency in university spin-offs, is about creativity and about adapting the venturing idea not just to the resources at hand (Baker and Nelson, 2005), but by also developing new competencies to bring the opportunity closer to market needs. The opportunity refinement competency can be seen as the ability to seek improvements in the opportunity combined with the ability to alter the opportunity according to new insights. For nascent university spin-offs, the opportunity refinement competency is dependent on a combination of high technological expertise combined with industry or market knowledge. Thus, interactions with industry were decisive for developing the initial business concept. This was a major challenge for the university spin-offs and appears to contrast with start-ups in general as the competency to enable these interactions had to be identified and developed. This leads to the following propositions:

Proposition 1a: The higher the proportion of career academics in the entrepreneurial team of nascent university spin-off ventures, the more industry experience has to be acquired for the entrepreneurial team to begin to identify and interact with industrial partners and customers. 
Proposition $1 b$ : Nascent university spin-off ventures are more likely to reach the credibility threshold if they evolve the venture's opportunity refinement competency through iteration of the entrepreneurial team, containing prior industry experience, with industry partners and customers.

To sum up, the opportunity refinement competency likely consists of an ability to discover opportunities based on scientific research and to further refine these opportunities into a viable business concept. The lack of ability to build on existing academic research skills to develop market related competencies without recruiting new team members and contacts appears particular to career academic entrepreneurs. Thus, entrepreneurial teams with a high portion of career academics likely need additional industry experience to be able to develop an opportunity refinement competency. Key characteristics of the opportunity refinement competency are presented in Table V.

\section{INSERT TABLE V HERE}

Leveraging competency. The second competency we identified related to the ability to acquire and combine resources to sustain the new venture creation process. University spin-offs are often associated with particularly high uncertainty and risk, and typically need a long time and significant investments to reach profitability. As a result, university spin-offs are likely dependent on contributions from several actors to be able to develop and acquire the resources they need. This was seen within Alpha where the four professors had prior joint experience from their research and consulting activities yet needed to develop their competencies by recruiting two team members with complementary competencies to their own. The Beta founders needed substantial support from the university to set up the new venture. Gamma received initial support from the TTO and then recruited an experienced management team. Delta similarly required TTO support to help attract industry partners.

The importance of gradually building credibility in order to acquire resources was explicitly referred to by many of our interviewees. In the initial phases of the venturing project, the focus was upon gaining credibility for the new venture within the university and to securing access to the requisite technology or IPR. For example, the Beta founders initially gained significant support within the university because their achievements through research and 
industry collaboration were widely recognised. It is at this stage that the university or its TTO often provided access to resources. For instance, the university management stepped forward to support the Beta project both internally and externally, and both Gamma and Delta received initial support from the TTO. Moreover the TTO often facilitated access to public funding sources, a crucial resource to enable the idea to be developed whilst credibility was low.

By contrast, later in the process, it became increasingly important to gain credibility among external investors by adding new members to the entrepreneurial team who had prior entrepreneurial experience. They were seen as necessary to help gain resources from investors, industry partners and customers. The benefits of this type of competency, often lacking within the university, were clearly explained by one of the founders of Delta:

'The firm we partnered with provided in-kind funding in the form of manufacturing systems for prototypes and test shelters. In addition they provide advice, collaboration and time. They provide market info as we have access to their customers who would make use of this technology so we have a route to market. They gave us an insight into how companies work with customers and how the system should be changed to meet customer needs'

Thus developing credibility may be a precursor for the ability to acquire resources (Zott and Huy, 2007). This was epitomised by case Alpha, where the founders were highly respected academics within industry, thereby making it easier to contact prospective customers and industry partners. After receiving initial funding from a large industry partner, Alpha gained a higher level of credibility, which made it easier to access other sources of resources, such as investors and customers.

It appears that the university environment is rich in some resources such as technological expertise and access to skilled personnel which bestows a limited level of credibility outside the university. Yet what is distinctive about the university environment is that key aspects of the leveraging competency are often lacking, such as how to access resources from industry partners and how to communicate with external investors (Wright et al., 2008). More generally it seems that habitual entrepreneurs possess this competency, while novice entrepreneurs may need more external assistance (Mosey and Wright, 2007). As a result, the leveraging competency is likely to reside with several individuals both within and outside the university. Thus, we propose that: 
Proposition 2a: The higher the proportion of career academics in the entrepreneurial team of nascent university spin-off ventures, the more likely the parent university organization, the university TTO, and public support schemes can assist the entrepreneurial team to begin to interact with external resource providers (such as industry partners and investors).

Proposition 2b: The higher the proportion of career academics in the entrepreneurial team of nascent university spin-off ventures, the more additional entrepreneurial experience has to be acquired for the entrepreneurial team to be able to gain resources from external resource providers (such as industry partners and investors).

Proposition 2c: Nascent university spin-off ventures are more likely to reach the credibility threshold if they can evolve the venture's leveraging competency through interaction of the entrepreneurial team, containing prior entrepreneurial experience, with external resource providers (such as industry partners and investors).

To sum up, the leveraging competency is the ability to develop and integrate the internal and external resources needed to develop the new spin-off venture (Table V). The leveraging competency can be defined as the ability to evolve the credibility and entrepreneurial experience needed by the nascent venture to gain access to resources. The nascent venture needs resources from several different sources, thus there is a need for credibility and experience in several arenas (university, industry partners, investor communities, etc). Due to the specialized research skills of academics, entrepreneurial teams with a high portion of career academics need additional support and entrepreneurial experience to be able to develop a leveraging competency. This means that many actors are involved in providing the leveraging competency.

Championing competency. The third competency we identified related to the personal commitment or the leadership role needed to sustain the venture start-up process (Table IV). Our cases illustrated very clearly the important role of champions. A division of championing roles may be necessary in complex, high-technology start-ups (Day, 1994). Our cases show that an effective team seems to be important in order to be able to respond to and deal with rapid changes in the business concept. Grandi and Grimaldi (2005) found that articulation of roles and prior joint experience positively influence business idea articulation of university 
spin-off ventures. Our cases show that the entrepreneurial motivation was often triggered in situations where slack resources allow key persons to focus their effort on the spin-off project. Thus, slack resources may be as important for spin-off activity as for innovation (Nohria and Gulati, 1996).

As with the other competencies, championing was not static. In our cases, the championing role changed as the venture emerged from developing internal support and credibility within the university context to developing external support and credibility towards industry partners, customers, and potential investors. Thus, academic researchers might be important champions initially, especially with respect to championing the technology, while persons with another background may be needed to champion the commercial aspects in later stages. Thus, the championing competency needs to be altered as the new venture matures (Clarysse and Moray, 2004). Our cases thus extend the argument that champions are particularly important in the early stages of new venture formation, before the business concept is clear and the initial resources acquired (Markham, 1998). Yet, these academic champions appear necessary but not sufficient. In all our cases, new champions had to be recruited to tackle the very different challenges encountered later in the start-up process. This was explained by the new Chairman of Beta who had previously worked as a venture capitalist:

'When the Beta founders contacted [Venture fund] two years ago [...] they were only seeking advice. [...] My first impression of the Beta founders was that they were very serious and solid professionals, and very interested in doing this in a proper way. [...] That I became chairman of the board happened gradually. I was involved by commenting on business plans and applications, and worked maybe 50 hours the first half-year. Then the process of finding investors started, and with my experience from the [Venture fund] I became involved in the funding strategy.'

In a similar vein, Alpha and Delta emphasize the important role played by 'godfathers'. That is, influential people in industry or other resource providers who make an additional effort to help the project. There were good examples of such influential individuals in all cases, such as the university managers in Beta and the experienced entrepreneur who became chairman of Gamma. The Gamma chairman became an effective champion within the external environment, albeit only after the inventor convinced him to join the venture, as explained by Gamma's founder: 
'I met our chairman at a regional investors' event. It was organized by the local development agency and the TTO encouraged me to go along and pitch our idea for VC investment. [...] (B1) came over to me at the buffet afterwards and started chatting. [...] He explained that he had founded three other university spin outs in the medical device field and gave me some great advice on how to sell my idea. I explained that we were short of cash but could he come and meet the team and see our kit. He agreed and got excited about the kit. He joined us pro bono and immediately signed up a superstar team. [...] We got our finance director, our marketing director, all with contacts into the industry.'

Thus, the internal champions in the entrepreneurial team are crucial, but also external individuals or people higher in the organization are needed for a sustainable championing competency. As discussed by Howell and Higgins (1990), champions induce the commitment of others to the innovation by providing emotional meaning and energy to the idea. Thus, we propose that in the context of university spin-offs there is a distinctive need to evolve the championing competency from the internal university context to also include external champions:

Proposition 3a: The higher the proportion of career academics in the entrepreneurial team of nascent university spin-off ventures, the more additional championing competency has to be acquired from individuals within the university.

Proposition 3b: Nascent university spin-off ventures are more likely to reach the credibility threshold if they can evolve the venture's championing competency by the entrepreneurial team, containing university champions, also mobilizing champions within external resource providers.

To sum up, the championing competency may be defined as the ability to identify with the venture and to convince others to contribute to its development (Table V). Championing is not only connected to individual entrepreneurs, but to the entrepreneurial team and to outside champions residing in other organizations. Due to the distinct research skills of academics, entrepreneurial teams with a high portion of career academics likely need additional champions within the university to be able to gain outside champions. Many people can have championing roles and these roles can be held by different people throughout the venturing 
process. It seems like a greater championing competency is needed the more complex the venture is. Compared to other studies of championing (Howell and Shea, 2001), our definition of championing is narrower, focusing only on the driving force and not the ability to spot opportunities and gain access to resources.

\section{DISCUSSION AND IMPLICATIONS}

By focusing on how nascent ventures overcome competency deficiencies to achieve credibility, we offer novel theoretical insights into the initial phases of the entrepreneurship process in the resource-constrained, traditionally non-supportive environments typically encountered by high-technology firms in universities. Specifically, we have proposed that the three competencies of opportunity refinement, leveraging, and championing are needed to successfully launch a university spin-off venture. We go beyond previous studies by showing that it is not sufficient to state that certain competencies are needed but that it is also necessary to identify who provides them and how they evolve. In some instances the competencies are built within the venture over time, while in other cases the competencies are acquired from sources outside the venture. We have offered propositions regarding the intricacies of how these competencies evolve in different ways.

Following Kuratko et al. (2005), we identify several aspects of entrepreneurial competency development and acquisition that appear to be particularly distinctive to the academic entrepreneurship context as they require departures from existing development paths (Ahuja and Katila, 2004). Accessing the industrial experience needed to develop the competency of opportunity refinement seems to be a distinctive challenge for academic entrepreneurs since this is less likely to be present in academic founding teams but may need to be created through iteration with industry partners and customers. Accessing resources from industrial partners and communicating to external investors is also a distinctive challenge for academic entrepreneurs seeking to gain credibility for their venture since the leveraging competency required may be lacking in the entrepreneurial team. However, academic entrepreneurs can obtain this from a variety of sources including actors both internal and external to the university. Gaining access to the championing competency to develop a venture is a further distinctive challenge of academic entrepreneurship. Given the general lack of industrial and entrepreneurial experience among academic entrepreneurs, gaining external champions residing within industrial partners or other resource providers may be particularly important in academic entrepreneurial ventures. 
Our competency approach extends entrepreneurship research in several ways. Prior research on entrepreneurial competencies has mainly looked at the characteristics of individual entrepreneurs (Man et al., 2002). Approaches focusing on the individual entrepreneur have been critiqued for exaggerating the role of single individuals, while studies looking at organizational structures and external environment tend to overlook the role of individuals. By focusing on the competencies provided by several actors, this study addresses the lack of multi-level approaches in entrepreneurship research (Davidsson and Wiklund, 2001) and contributes to a better understanding of how entrepreneurial processes result from interactions among a broad array of actors.

Furthermore, the competency approach developed in this paper goes beyond previous research that has tended to focus on associations that exist at one point in time to explore the mechanisms that lead to changes over time (Van de Ven and Hargrave, 2004). Thus, we offer a more inclusive framework to understand the initial phases of the venturing process taking into account the individuals, the context, and how the process evolves temporally.

This research also contributes to knowledge about the role of the institutional incubator environment of high-technology ventures. These firms face a duality of challenges due to the typically fast moving environment within which they compete and the long timescale before they gain a competitive advantage (Shane, 2001). We propose that a pragmatic response to that challenge is the evolution of competencies to allow for the repeated reconfiguration of resources necessary to balance the ever changing needs of investors, partners, and potential customers. In an incubator environment where the necessary competencies are lacking, such as within universities, the competencies may be created by the interaction of several actors. We show how the evolution of these competencies depends on the starting configuration and context of the nascent venture. Although actors from outside this context are needed for the venture to reach the credibility threshold, the initial focus of the venture is framed by the academic environment, rather than by commercial concerns.

This study also keys into the theoretical gap of how the initial resources for a new venture are assembled (Ahuja and Katila, 2004; Greene et al., 1999). By investigating the initial phases of venture emergence, we shed light on where firm capabilities may originate. As asserted by Teece and Pisano (1994), organizations need to renew their competencies in order to respond 
to shifts in the business environment. Yet as more recently argued by Ahuja and Katila (2004), such renewal may need to occur not only along existing trajectories but also by creating new ones. By examining university spin-offs we expand understanding of when and how new directions for creating competencies occur since they involve idiosyncratic situations where traditional non-commercial competencies are of limited relevance. In this context, the challenge is not just to develop further high-technology innovation competencies but to develop competencies to be able to frame innovations commercially. A key distinction that emerges is the need to identify the different (internal and external) actors who can make the bridge between the academic and commercial environments. Although the role of industry experience and networks among the academic entrepreneurs has been pointed out by many studies, our study has identified the important role played by industry partners, what competencies they provide, and how these competencies and resources are accessed by the academic entrepreneurs.

\section{Limitations and research implications}

Because entrepreneurship is a dynamic process, theorizing on particular phases of development is justified (Shane et al., 2003). It is unlikely that one model can describe the entire process from initial idea to established venture. Our model has theorized the process leading to the credibility threshold, while other factors may have influence upon the further survival and growth of the venture. Whether the competencies and the sources identified in this study are associated with higher survival rates and superior performance needs further investigation.

Another question emerging from this study is what competencies are exclusive to the start-up process and what competencies are important for the further operation and development of the new firm. These questions are important for the decision about what competencies should be internal to the entrepreneurial team and the venture, and what competencies should be accessed from external actors. It might be an advantage if competencies that are needed only during a limited period of the venture development are provided by external actors, because these competencies then will be easier to dispose of when they become obsolete. Thus, it is important that the more enduring or core competencies are built within the new firm.

This study has investigated research-based ventures emerging in a university context, but the competencies may be relevant in other settings as well. Particularly in complex contexts were 
many individuals and actors are involved in developing nascent ventures with an uncertain outcome. Thus, the competency perspective could be relevant to study the start-up process of new technology-based firms in general, new product development processes involving several organizations or units, and processes of institutional entrepreneurship. The competency framework is promising to reveal specific differences of entrepreneurial processes in different contexts.

The use of a qualitative approach has provided an in-depth understanding of the competencies used in the initial phases of new venture formation. By following the cases over time, we have been able to observe the dynamic aspects of these competencies. The use of theoretical sampling covering different contexts provides some confidence that the patterns identified are likely to reflect those of other start-up processes. Still, our study is limited to four cases and should be replicated in other national, university, and industry settings for further validation and refinement. Larger samples and longitudinal research designs following the development of competencies over time and the outcome of the process are warranted in order properly test the propositions.

\section{Managerial implications}

By defining a set of three competencies necessary for spin-off firm formation this study identifies some implications for practice. Many of the competencies needed in initial venture development can only be supported indirectly as both the competencies and the networks to access such competencies need to be built over time. For instance, the opportunity refinement competency seems to be dependent on industry experience and interaction, the leveraging competency is related to the credibility and entrepreneurial experience of the entrepreneurial team, and the championing competency is related to individual motivations.

The different nature of the three competencies implies that universities and government cannot apply the same policies and schemes to support the development of each competency. Opportunity refinement often depends on interaction with customers or industry, while the championing competency may be related to cultural factors, prior experience, and incentives. Since opportunity refinement and championing competencies have a stronger connection to the individuals involved, the influence by policy makers can only be more indirect. In contrast, leveraging is dependent on a range of factors that can be supported more directly by many different actors. Universities and support actors are well-placed to assist in accessing 
and acquiring resources, for instance by building legitimacy and networks that provide access to resources. Thus, the competency perspective is useful for research institutions in developing their incubation strategies (Clarysse et al., 2005).

Moreover, the competency approach is highly appropriate to draw implications for training and providing support for entrepreneurs. This approach can be a tool for assessing the existing competencies of an individual or team, thus highlighting areas needing further training or additional support. Also, the entrepreneurs can deliberately build strong teams where the different team members complement each other’s competencies.

\section{CONCLUSIONS}

In conclusion, adopting a competency approach allowed us to gain insight into a complex, dynamic, and multi level process that is poorly understood. By focussing upon a specific stage of venture creation and a particular context that is infrequently studied, we were able to develop more inclusive theory. It appears that universities represent a somewhat schizophrenic institutional environment where they have a strategic aim to support new venture creation but typically lack many of the competencies necessary to achieve that aim. We aimed to gain a better understanding of the evolution of competencies and have built theory that helps to reconcile disparate findings from prior studies of new venture emergence.

\section{ACKNOWLEDGEMENT}

The first author would like to thank the Centre for Management Buy-Out Research (CMBOR) at the University of Nottingham Business School for hosting him as a visiting scholar during the time this paper was written and the Research Council of Norway for financial support. The authors would like to thank the informants for generously sharing their experiences and the seminar participants at the University of Durham and Claire Leitch for valuable feedback to an earlier version of the manuscript. Finally, we want to thank the three anonymous reviewers, Jeff Covin and Andrew Delios, whose feedback has greatly benefited this article. 


\section{REFERENCES}

Agrawal, A. (2006). Engaging the inventor: Exploring licensing strategies for university inventions and the role of latent knowledge. Strategic Management Journal, 27(1), 6379.

Ahuja, G., \& Katila, R. (2004). Where do resources come from? The role of idiosyncratic situations. Strategic Management Journal, 25, 887-907.

Almeida, P., \& Kogut, B. (1999). Localization of Knowledge and the Mobility of Engineers in Regional Networks. Management Science, 45(7), 905-917.

Alvarez, S. A., \& Barney, J. B. (2007). The Entrepreneurial Theory of the Firm. Journal of Management Studies, 44(7), 1057-1063.

Alvarez, S. A., \& Busenitz, L. W. (2001). The entrepreneurship of resource-based theory. Journal of Management, 27(6), 755-775.

Ambos, T. C., Mäkelä, K., Birkinshaw, J., \& D'Este, P. (2008). When Does University Research Get Commercialized? Creating Ambidexterity in Research Institutions. Journal of Management Studies, 45(8), 1424-1447.

Ardichvili, A., Cardozo, R., \& Ray, S. (2003). A theory of entrepreneurial opportunity identification and development. Journal of Business Venturing, 18(1), 105-123.

Baker, T., \& Nelson, R. E. (2005). Creating something from nothing: Resource construction through entrepreneurial bricolage. Administrative Science Quarterly, 50(3), 329-366.

Bhave, M. P. (1994). A Process Model of Entrepreneurial Venture Creation. Journal of Business Venturing, 9(3), 223-242.

Burgelman, R. (1983). A Process Model for Internal Corporate Venturing in the Diversified Major Firm. Administrative Science Quarterly, 28(3), 223-244.

Chandler, G. N., \& Hanks, S. H. (1994). Founder competence, the environment, and venture performance. Entrepreneurship Theory and Practice, 18(3), 77-89.

Clarysse, B., \& Moray, N. (2004). A process study of entrepreneurial team formation: the case of a research-based spin-off. Journal of Business Venturing, 19(1), 55-79.

Clarysse, B., Wright, M., Lockett, A., de Velde, E. V., \& Vohora, A. (2005). Spinning out new ventures: a typology of incubation strategies from European research institutions. Journal of Business Venturing, 20(2), 183-216.

Colombo, M., \& Grilli, L. (2005). Founders' human capital and the growth of new technology-based firms: A competence-based view. Research Policy, 34(6), 795-816.

Conner, K. (1991). A Historical Comparison of Resource-Based Theory and Five Schools of Thought within Industrial Organization Economics: Do We Have a New Theory of the Firm. Journal of Management, 17(1), 121-154.

Cooper, A. C., Gimeno-Gascon, F. J., \& Woo, C. Y. (1994). Initial human and financial capital as predictors of new venture performance. Journal of Business Venturing, 9(5), 371-395.

Czarniawska, B. (1998). A narrative approach to organization studies. London: Sage.

Danneels, E. (2002). The dynamics of product innovation and firm competences. Strategic Management Journal, 23(12), 1095-1121.

Davidsson, P., \& Honig, B. (2003). The role of social and human capital among nascent entrepreneurs. Journal of Business Venturing, 18(3), 301-331.

Davidsson, P., \& Wiklund, J. (2001). Levels of analysis in entrepreneurship research: current research practice and suggestions for the future. Entrepreneurship Theory and Practice, 25(4), 81-99.

Day, D. L. (1994). Raising Radicals - Different Processes for Championing Innovative Corporate Ventures. Organization Science, 5(2), 148-172. 
Di Gregorio, D., \& Shane, S. (2003). Why do some universities generate more start-ups than others? Research Policy, 32(2), 209-227.

Dobrev, S. D., \& Barnett, W. P. (2005). Organizational roles and transition to entrepreneurship. Academy of Management Journal, 48(3), 433-449.

Downward, P., \& Mearman, A. (2007). Retroduction as mixed-methods triangulation in economic research: reorienting economics into social science. Cambridge Journal of Economics, 31(1), 77-99.

Druilhe, C. 1., \& Garnsey, E. (2004). Do Academic Spin-Outs Differ and Does it Matter? The Journal of Technology Transfer, 29(3/4), 269-285.

Eisenhardt, K. M. (1989). Building Theories from Case-Study Research. Academy of Management Review, 14(4), 532-550.

Franklin, S., Wright, M., \& Lockett, A. (2001). Academic and surrogate entrepreneurs in university spin-out companies. Journal of Technology Transfer, 26(1/2), 127-141.

Gnyawali, D. R., \& Fogel, D. S. (1994). Environments for Entrepreneurship Development: Key Dimensions and Research Implications. Entrepreneurship Theory and Practice, 18(4), 43-62.

Godfrey, P. C., \& Gregerson, H. B. (1999). Where do resources come from? A model of resource generation. The Journal of High Technology Management Research, 10(1), 37-60.

Grandi, A., \& Grimaldi, R. (2005). Academics' organizational characteristics and the generation of successful business ideas. Journal of Business Venturing, 20(6), 821845.

Greene, P. G., Brush, C. G., \& Hart, M. M. (1999). The corporate venture champion: A resource-based approach to role and process. Entrepreneurship Theory and Practice, 23(Spring), 103-122.

Hayton, J. C., \& Kelley, D. J. (2006). A competency based framework for promoting corporate entrepreneurship. Human Resource Management, 45(3), 407-427.

Heirman, A., \& Clarysse, B. (2004). How and Why do Research-Based Start-Ups Differ at Founding? A Resource-Based Configurational Perspective. The Journal of Technology Transfer, 29(3/4), 247-268.

Howell, J. M., \& Higgins, C. A. (1990). Champions of Technological Innovation. Administrative Science Quarterly, 35(2), 317-341.

Howell, J. M., \& Shea, C. M. (2001). Individual differences, environmental scanning, innovation framing, and champion behavior: key predictors of project performance. Journal of Product Innovation Management, 18(1), 15-27.

Jong, S. (2006). How organizational structures in science shape spin-off firms: the biochemistry departments of Berkeley, Stanford, and UCSF and the birth of the biotech industry. Industrial and Corporate Change, 15(2), 251-283.

Kenney, M., \& Goe, W. R. (2004). The role of social embeddedness in professional entrepreneurship: a comparison of electrical engineering and computer science at UC Berkley and Stanford. Research Policy, 33(5), 679-844.

Khavul, S., Brush, C., Kalish, S., \& Lerner, M. (1998). Public policy and private initiative in the incubation of Israeli high technology entrepreneurial firms. Paper presented at the Babson Entrepreneurship Conference.

Klepper, S., \& Sleeper, S. (2005). Entry by spinoffs. Management Science, 51(8), 1291-1306.

Kuratko, D. F., Ireland, R. D., Covin, J. G., \& Hornsby, J. S. (2005). A model of middle-level managers' entrepreneurial behavior. Entrepreneurship Theory and Practice, 29(6), 699-716.

Leca, B., \& Naccache, P. (2006). A critical realist approach to institutional entrepreneurship. Organization, 13(5), 627-651. 
Lee, Y. S. (1996). 'Technology transfer' and the research university: A search for the boundaries of university-industry collaboration. Research Policy, 25(6), 843-863.

Lichtenstein, B. B., Dooley, K. J., \& Lumpkin, G. T. (2006). Measuring emergence in the dynamics of new venture creation. Journal of Business Venturing, 21(2), 153-175.

Lichtenstein, B. M. B., \& Brush, C. G. (2001). How Do "Resource Bundles" Develop and Change in New Ventures? A Dynamic Model and Longitudinal Exploration. Entrepreneurship Theory and Practice, 25(Spring), 37-58.

Lockett, A., \& Wright, M. (2005). Resources, capabilities, risk capital and the creation of university spin-out companies. Research Policy, 34(7), 1043-1057.

Lockett, A., Wright, M., \& Franklin, S. (2003). Technology transfer and universities' spin-out strategies. Small Business Economics, 20(2), 185-200.

Man, T. W. Y., Lau, T., \& Chan, K. F. (2002). The competitiveness of small and medium enterprises - A conceptualization with focus on entrepreneurial competencies. Journal of Business Venturing, 17(2), 123-142.

Markham, S. K. (1998). A longitudinal examination of how champions influence others to support their projects. Journal of Product Innovation Management, 15(6), 490-504.

Markman, G. D., Siegel, D. S., \& Wright, M. (2008). Research and Technology Commercialization. Journal of Management Studies, 45(8), 1401-1423.

Mosey, S., \& Wright, M. (2007). From human Capital to social capital: a longitudinal study of technology-based academic entrepreneurs. Entrepreneurship Theory and Practice, 31(November), 909-935.

Mustar, P., Renault, M., Colombo, M. G., Piva, E., Fontes, M., Lockett, A., et al. (2006). Conceptualizing the heterogeneity of research-based spin-offs: a multi dimensional taxonomy. Research Policy, 35(2), 289-308.

Neck, H. M., Meyer, G. D., Cohen, B., \& Corbett, A. C. (2004). An entrepreneurial system view of new venture creation. Journal of Small Business Management, 42(2), 190-208.

Nohria, N., \& Gulati, R. (1996). Is slack good or bad for innovation? Academy of Management Journal, 39(5), 1245-1264.

Orton, J. D. (1997). From inductive to iterative grounded theory: zipping the gap between process theory and process data. Scandinavian Journal of Management, 13(4), 419438.

Penrose, E. (1959). The Theory of the Growth of the Firm. Oxford: Blackwell.

Pettigrew, A. (1990). Longitudinal field research on change: theory and practice. Organization Science, 1(3), 267-292.

Phan, P., Siegel, D. S., \& Wright, M. (2005). Science parks and incubators: observations, synthesis and future research. Journal of Business Venturing, 20(2), 165-182.

Polkinghorne, D. E. (1988). Narrative knowing and the human sciences. Albany: State University of New York Press.

Roberts, E. B. (1991). Entrepreneurs in high technology: lessons from MIT and beyond. New York: Oxford University Press.

Rothaermel, F. T., Agung, S. D., \& Jiang, L. (2007). University entrepreneurship: a taxonomy of the literature. Ind Corp Change, 16(4), 691-791.

Sapienza, H. J., Parhankangas, A., \& Autio, E. (2004). Knowledge relatedness and post-spinoff growth. Journal of Business Venturing, 19(6), 809-829.

Sarasvathy, S. D. (2001). Causation and Effectuation: Toward a Theoretical Shift from Economic Inevitability to Entrepreneurial Contingency. Academy of Management Review, 26(2), 243-263.

Shane, S. (2001). Technological Opportunities and New Firm Creation. Management Science, 47(2), 205-220. 
Shane, S. (2004). Academic entrepreneurship -University spinoffs and wealth creation. Cheltenham: Edward Elgar Publishing, Inc.

Shane, S., Locke, E. A., \& Collins, C. J. (2003). Entrepreneurial motivation. Human Resource Management Review, 13, 257-279.

Shane, S., \& Stuart, T. (2002). Organizational endowments and the performance of university start-ups. Management Science, 48(1), 154-170.

Smilor, R. W., Gibson, D. V., \& Dietrich, G. B. (1990). University Spin-out Companies Technology Start-Ups from University-of-Texas-at-Austin. Journal of Business Venturing, 5(1), 63-76.

Suddaby, R. (2006). From the editors: What grounded theory is not. Academy of Management Journal, 49(4), 633-642.

Taylor, S., \& Bodgan, R. (1984). Introduction to qualitative research: The search for meanings. New York: Wiley.

Teece, D., \& Pisano, G. (1994). The Dynamic Capabilities of Firms: an Introduction. Industrial and Corporate Change, 3(3), 537-a-556.

Van de Ven, A. H., \& Hargrave, T. J. (2004). Social, technical, and institutional change: a literature review and synthesis. In M. S. Poole \& A. H. Van de Ven (Eds.), Handbook of organizational change and innovation (pp. 259-303). Oxford: Oxford University Press.

Van de Ven, A. H., \& Poole, M. S. (2002). Field research methods. In J. A. C. Baum (Ed.), Companion to Organizations (pp. 867-888). Oxford: Blackwell.

Vanaelst, I., Clarysse, B., Wright, M., Lockett, A., Moray, N., \& S'Jegers, R. (2006). Entrepreneurial Team Development in Academic Spinouts: An Examination of Team Heterogeneity. Entrepreneurship Theory and Practice, 30(2), 249-271.

Vohora, A., Wright, M., \& Lockett, A. (2004). Critical junctures in the development of university high-tech spinout companies. Research Policy, 33(1), 147-175.

Westhead, P., \& Storey, D. J. (1995). Links between higher-education institutions and hightechnology firms. Omega, 23(4), 345-360.

Wright, M., Clarysse, B., Lockett, A., \& Knockaert, M. (2008). Mid-range universities' linkages with industry: Knowledge types and the role of intermediaries. Research Policy, 37(8), 1205-1223.

Wright, M., Clarysse, B., Mustar, P., \& Lockett, A. (2007). Academic entrepreneurship in Europe. Cheltenham: Edward Elgar.

Yin, R. K. (1989). Case study research. Design and methods (Vol. Vol 5). Newbury Park: SAGE Publications Ltd.

Zahra, S. A., \& Nielsen, A. P. (2002). Sources of capabilities, integration and technology commercialization. Strategic Management Journal, 23(5), 377-398.

Zahra, S. A., Sapienza, H. J., \& Davidsson, P. (2006). Entrepreneurship and dynamic capabilities: A review, model and research agenda. Journal of Management Studies, 43(4), 917-955.

Zimmerman, M. A., \& Zeitz, G. J. (2002). Beyond survival: Achieving new venture growth by building legitimacy. Academy of Management Review, 27(3), 414-431.

Zott, C., \& Huy, Q. N. (2007). How entrepreneurs use symbolic management to acquire resources. Administrative Science Quarterly, 52(1), 70-105.

Zucker, L. G., Darby, M. R., \& Brewer, M. B. (1998). Intellectual Human Capital and the Birth of U.S. Biotechnology Enterprises. American Economical Review, 88(1), 290305. 
Table I. Characteristics of the case universities in Norway (NO) and the UK

\begin{tabular}{|c|c|c|c|c|}
\hline & University A (NO) & University B (NO) & University C (UK) & University D (UK) \\
\hline Age & About 100 years & About 30 years & About 100 years & About 50 years \\
\hline $\begin{array}{l}\text { Important fields } \\
\text { of research }\end{array}$ & $\begin{array}{l}\text { Technology, } \\
\text { engineering, natural } \\
\text { sciences, social } \\
\text { science, medicine }\end{array}$ & $\begin{array}{l}\text { Social science, natural } \\
\text { sciences, medicine }\end{array}$ & $\begin{array}{l}\text { Technology, } \\
\text { engineering, natural } \\
\text { sciences, social } \\
\text { science, medicine }\end{array}$ & $\begin{array}{l}\text { Technology, } \\
\text { engineering, natural } \\
\text { sciences, social } \\
\text { science }\end{array}$ \\
\hline $\begin{array}{l}\text { Annual research } \\
\text { budget } 2003\end{array}$ & $\begin{array}{l}\text { About } 200 \text { million } \\
\text { EUR }\end{array}$ & $\begin{array}{l}\text { About } 90 \text { million } \\
\text { EUR }\end{array}$ & $\begin{array}{l}\text { About } 180 \text { million } \\
\text { EUR }\end{array}$ & $\begin{array}{l}\text { About } 60 \text { million } \\
\text { EUR }\end{array}$ \\
\hline $\begin{array}{l}\text { Industry share of } \\
\text { research budget }\end{array}$ & $9.8 \%$ & $2.0 \%$ & $29 \%$ & $32 \%$ \\
\hline $\begin{array}{l}\text { Spin-off } \\
\text { experience }\end{array}$ & $\begin{array}{l}\text { Many examples of } \\
\text { spin-offs }\end{array}$ & $\begin{array}{l}\text { Few examples of } \\
\text { spin-offs }\end{array}$ & $\begin{array}{l}\text { Many examples of } \\
\text { spin-offs }\end{array}$ & $\begin{array}{l}\text { Many examples of } \\
\text { spin-offs }\end{array}$ \\
\hline $\begin{array}{l}\text { Spin-off support } \\
\text { system (year } \\
\text { established) }\end{array}$ & $\begin{array}{l}\text { Science park (1980s), } \\
\text { Entrepreneurship } \\
\text { Center (1980s), } \\
\text { Science park } \\
\text { incubator 1990s), } \\
\text { University on-campus } \\
\text { incubator (2001), } \\
\text { TTO (2003) }\end{array}$ & $\begin{array}{l}\text { Science park (1990s), } \\
\text { Science park } \\
\text { incubator (2000), } \\
\text { TTO (2004) }\end{array}$ & $\begin{array}{l}\text { Science park (1980s) } \\
\text { TTO (1985) } \\
\text { Entrepreneurship } \\
\text { Center (1990s) } \\
\text { Science park } \\
\text { incubator (1990s) } \\
\text { University on-campus } \\
\text { incubator (1990s) }\end{array}$ & $\begin{array}{l}\text { Science park (1990s) } \\
\text { TTO (1996) } \\
\text { Entrepreneurship } \\
\text { Center (2000) Science } \\
\text { park incubator (2001) } \\
\text { University on-campus } \\
\text { incubator (2002) }\end{array}$ \\
\hline
\end{tabular}


Table II. Central properties of the spin-off cases

\begin{tabular}{|c|c|c|c|c|}
\hline & Alpha (A) & Beta (B) & Gamma (C) & Delta (D) \\
\hline Founder(s) & Four professors & Two professors & $\begin{array}{l}\text { One senior lecturer } \\
\text { one post doc }\end{array}$ & Two Professors \\
\hline $\begin{array}{l}\text { Additional team } \\
\text { members }\end{array}$ & $\begin{array}{l}\text { Experienced } \\
\text { entrepreneur and } \\
\text { lawyer }\end{array}$ & $\begin{array}{l}\text { Two experienced } \\
\text { business developers } \\
\text { and chairman of } \\
\text { board }\end{array}$ & $\begin{array}{l}\text { Experienced } \\
\text { chairman, finance } \\
\text { and marketing } \\
\text { directors }\end{array}$ & Industry partners \\
\hline Founded & 2003 & 2003 & 2002 & 2003 \\
\hline $\begin{array}{l}\text { Number of } \\
\text { employees in } 2006\end{array}$ & 17 & 12 & 8 & 10 \\
\hline $\begin{array}{l}\text { Time from research } \\
\text { idea to spin-off }\end{array}$ & 14 years & $\sim 8$ years & $\sim 15$ years & 10 years \\
\hline University ownership & No & Yes, major & Yes, minor & Yes, minor \\
\hline First premises & University incubator & $\begin{array}{l}\text { Science park } \\
\text { incubator }\end{array}$ & City incubator & University incubator \\
\hline Main R\&D partner & Industry & University & University & Industry \\
\hline $\begin{array}{l}\text { Main source of idea } \\
\text { development }\end{array}$ & $\begin{array}{l}\text { One professor's } \\
\text { industrial experience }\end{array}$ & $\begin{array}{l}\text { Professors' prior } \\
\text { industry cooperation }\end{array}$ & $\begin{array}{l}\text { Post doc's industrial } \\
\text { experience }\end{array}$ & $\begin{array}{l}\text { Post doc's } \\
\text { networking }\end{array}$ \\
\hline Field of research & Engineering & Biomedical & Biomedical & Engineering \\
\hline Product & Software & Medicine & Medical device & Electro-mechanical \\
\hline Business model & $\begin{array}{l}\text { Software and } \\
\text { services }\end{array}$ & $\begin{array}{l}\text { Development } \\
\text { company }\end{array}$ & $\begin{array}{l}\text { Development } \\
\text { company }\end{array}$ & $\begin{array}{l}\text { Development } \\
\text { company }\end{array}$ \\
\hline Initial funding & $\begin{array}{l}\text { Public funding and } \\
\text { development grants } \\
\text { from industry } \\
\sim £ 4000 \mathrm{k}\end{array}$ & $\begin{array}{l}\text { Public funding } \\
\sim £ 200 \mathrm{k}\end{array}$ & $\begin{array}{l}\text { Proof of concept } \\
\text { public fund } \\
£ 50 \mathrm{k}\end{array}$ & $\begin{array}{l}\text { Proof of concept } \\
\text { public fund } \\
£ 50 \mathrm{k}\end{array}$ \\
\hline $\begin{array}{l}\text { Second round of } \\
\text { funding }\end{array}$ & $\begin{array}{l}\text { Industry partner } \\
\text { provide equity } \\
\text { investment } \\
\sim £ 1500 \mathrm{k}\end{array}$ & $\begin{array}{l}\text { Private placement } \\
\sim £ 300 \mathrm{k}\end{array}$ & $\begin{array}{l}\text { Government } \\
\text { development grant } \\
\text { and fellowship fund } \\
£ 130 \mathrm{k}\end{array}$ & $\begin{array}{l}\text { Government } \\
\text { development grant } \\
\text { and fellowship fund } \\
£ 110 \mathrm{k}\end{array}$ \\
\hline $\begin{array}{l}\text { Further rounds of } \\
\text { funding }\end{array}$ & $\begin{array}{l}\text { Equity investment by } \\
\text { industry partner and } \\
\text { employees } \\
\sim £ 500 \mathrm{k}\end{array}$ & $\begin{array}{l}\text { Several rounds of } \\
\text { private placements, } \\
(>20 \text { owners }) \\
\sim £ 400+£ 1600 \mathrm{k}\end{array}$ & $\begin{array}{l}\text { Equity investment by } \\
\text { Venture Capitalist } \\
\sim £ 500 \mathrm{k}\end{array}$ & $\begin{array}{l}\text { Equity investment by } \\
\text { industry partner } \\
\sim £ 350 \mathrm{~K}\end{array}$ \\
\hline
\end{tabular}


Table III. Persons interviewed (number of interviews in parenthesis)

\begin{tabular}{|c|c|c|c|c|}
\hline & Alpha (A) & Beta (University B) & Gamma (C) & Delta (D) \\
\hline Founders (F) & $\begin{array}{l}\text { Professor F1 (4) } \\
\text { Professor F2 (2) } \\
\text { Professor F3 (2) } \\
\text { Professor F4 (2) }\end{array}$ & $\begin{array}{l}\text { Professor F1 (3) } \\
\text { Professor F2 (1) }\end{array}$ & $\begin{array}{l}\text { Senior lecturer F1 (4) } \\
\text { Post doc F2 (4) }\end{array}$ & $\begin{array}{l}\text { Professor F1 (2) } \\
\text { Professor F2 (2) }\end{array}$ \\
\hline $\begin{array}{l}\text { Team } \\
\text { members }(\mathrm{T})\end{array}$ & $\begin{array}{l}\text { Business developer } \\
\text { T1 (3) } \\
\text { Lawyer T2 (1) }\end{array}$ & $\begin{array}{l}\text { Bus. developer T1 (1) } \\
\text { Bus. developer T2 (1) } \\
\text { Administrative support T3 (1) }\end{array}$ & Researcher T1 (1) & Post doc T1 (2) \\
\hline $\begin{array}{l}\text { Board } \\
\text { members (B) }\end{array}$ & Same as founders & $\begin{array}{l}\text { First chairman B1 (1) } \\
\text { New chairman B2 (1) }\end{array}$ & $\begin{array}{l}\text { Chairman B1 (1) } \\
\text { Finance Director B2 (1) }\end{array}$ & Same as founders \\
\hline $\begin{array}{l}\text { University } \\
\text { management } \\
\text { (U) }\end{array}$ & $\begin{array}{l}\text { Department } \\
\text { manager U1 (1) }\end{array}$ & $\begin{array}{l}\text { University manager U1 (1) } \\
\text { Department manager U2 (1) } \\
\text { Department manager U3 (1) } \\
\text { Dean U4 (1) }\end{array}$ & $\begin{array}{l}\text { Department manager } \\
\text { U1 (1) }\end{array}$ & $\begin{array}{l}\text { Department } \\
\text { manager U1 (1) }\end{array}$ \\
\hline $\begin{array}{l}\text { Support } \\
\text { actors (S) }\end{array}$ & $\begin{array}{l}\text { TTO CEO S1 (1) } \\
\text { TTO Business } \\
\text { developer S2 (1) }\end{array}$ & $\begin{array}{l}\text { CEO science park S1 (1) } \\
\text { University administrator S2 (1) } \\
\text { University administrator S3 (1) }\end{array}$ & TTO S1 (1) & TTO S1 (1) \\
\hline Others $(\mathrm{O})$ & & Informal advisor O1 (1) & & $\begin{array}{l}\text { Development } \\
\text { partner O1 (1) }\end{array}$ \\
\hline $\begin{array}{l}\text { Total \# of } \\
\text { interviews* }\end{array}$ & 16 & 16 & 13 & 9 \\
\hline $\begin{array}{l}\text { University } \\
\text { visits }\end{array}$ & 6 & 4 & 7 & 6 \\
\hline $\begin{array}{l}\text { Secondary } \\
\text { sources }\end{array}$ & $\begin{array}{l}\text { Company } \\
\text { presentations } \\
\text { Business plan } \\
\text { Press articles }\end{array}$ & $\begin{array}{l}\text { Company presentations } \\
\text { Business plan } \\
\text { Press articles }\end{array}$ & $\begin{array}{l}\text { Company presentations } \\
\text { Business plans } \\
\text { Press articles }\end{array}$ & $\begin{array}{l}\text { Company } \\
\text { presentations } \\
\text { Business plans } \\
\text { Press articles }\end{array}$ \\
\hline
\end{tabular}

*The total number of interviews is less than the sum of persons interviewed because some interviews were done with more than one person and some persons have more than one position. 


\begin{tabular}{|c|c|c|c|}
\hline Case & Opportunity refinement & Resource leveraging & Championing \\
\hline Alpha & $\begin{array}{l}\text { One of the founders pursued a career in } \\
\text { industry for ten years before returning as } \\
\text { Professor at the university. The decision to try } \\
\text { to start a new venture came as a result of } \\
\text { informal discussions. 'The initial idea was } \\
\text { different [...] but [Professor x] came up with } \\
\text { the current concept based on his industry } \\
\text { experience [...] and then the ball started to } \\
\text { roll.' (F2) } \\
\text { External competency was mobilized in order } \\
\text { to develop the business idea further. 'The } \\
\text { business idea changed a lot during the first } \\
\text { discussions among the founding team and it } \\
\text { was further refined during an interactive } \\
\text { process involving industry and customers. } \\
\text { [...] 'the final idea was a result of an iterative } \\
\text { process with [Industry partner] and the ideas } \\
\text { we initially started with.' (F2) } \\
\text { 'The first idea was not right. [Industry } \\
\text { partner] did not see any value in it. We had } \\
\text { several rounds to better understand them from } \\
\text { the inside so that we could adapt our ideas. } \\
\text { The first half year was an iteration with } \\
\text { [Industry partner]. We had numerous meeting } \\
\text { at all levels to understand how they think. This } \\
\text { was a heavy period, but very decisive.' (F2) }\end{array}$ & $\begin{array}{l}\text { The professors deliberately acquired resources to } \\
\text { realize the venture. 'None of us had started a } \\
\text { business like this before, and we were aware that } \\
\text { there was a lot we did not know about such a } \\
\text { process. [Professor] knew [Business consultant] who } \\
\text { had been involved in many start-ups, and he also } \\
\text { joined the team. In addition we needed some legal } \\
\text { competency, and [Lawyer] joined the team as } \\
\text { chairman of the board.' (F4) } \\
\text { The university were a fruitful environment for } \\
\text { accessing the resources needed. 'Because we are } \\
\text { lacking knowledge in some areas, we have to hire } \\
\text { people with key competencies. [...] We are in a very } \\
\text { good position here at [University campus], with } \\
\text { good access to much professional expertise.' (F1) } \\
\text { The professors had broad networks in industry. 'Both } \\
\text { [Professor] and I had prior knowledge and contacts } \\
\text { in [Industry partner] that were used. The alliance } \\
\text { with [Industry partner] has created a 'domino effect' } \\
\text { related to other customers.' (F4) } \\
\text { The access to resources was dependent on the } \\
\text { credibility of the entrepreneurial team. 'When we } \\
\text { enter a meeting and say that we are four professors, } \\
\text { one business lawyer and an experienced } \\
\text { entrepreneur in the team, we are accepted } \\
\text { immediately. This gives us credibility.' (F2) }\end{array}$ & $\begin{array}{l}\text { When the spin-off idea came up, each professor } \\
\text { had for different reasons reduced their relation } \\
\text { to their main industrial partner. The professors } \\
\text { decided to explore the possibility to start a new } \\
\text { venture based on their research based } \\
\text { competency combined with their industrial } \\
\text { knowledge. 'We had achieved much [in } \\
\text { research], but this was something new. We were } \\
\text { also trigged by the opportunity to do this } \\
\text { together. We were in a way pushed forward by } \\
\text { each other.' (F4) } \\
\text { The professors were in a position that made it } \\
\text { possible to spend time on this activity. 'All } \\
\text { professors in Alpha are well above average in } \\
\text { productivity, so teaching and research is taken } \\
\text { care of. The effort in [Alpha] equals what } \\
\text { alternatively would be spent on consulting and } \\
\text { other projects.' (F1) } \\
\text { External persons located in other organizations } \\
\text { such as industry partners and government } \\
\text { support agencies also contributed to move the } \\
\text { project forward. One of the founders labels these } \\
\text { as 'godfathers' who took action to help in } \\
\text { difficult periods. 'Also in [Industry partner] } \\
\text { there was an internal 'godfather' who believed } \\
\text { in the project and championed it internally. [...] } \\
\text { Without the help of these 'godfathers' it would } \\
\text { have been difficult to get further.' (F4) }\end{array}$ \\
\hline Beta & $\begin{array}{l}\text { A group of university researchers discovered a } \\
\text { novel medical effect and further research was } \\
\text { funded by a pharmaceutical company and } \\
\text { public sources. The company made a general }\end{array}$ & $\begin{array}{l}\text { In the initial period the two professors received } \\
\text { considerable support from the university in the form } \\
\text { of financial and administrative resources, power in } \\
\text { the negotiations with industry partner, and internal }\end{array}$ & $\begin{array}{l}\text { One of the founders explained how they worked } \\
\text { as a team in taking a championing role: 'An } \\
\text { important point is that it is much easier to be } \\
\text { two. Things go in waves, and sometimes it is }\end{array}$ \\
\hline
\end{tabular}




\begin{tabular}{|c|c|c|c|}
\hline & $\begin{array}{l}\text { decision to pull out of such projects. To create } \\
\text { a spin-off venture became a new challenge to } \\
\text { the research team. } \\
\text { To match the scientific findings with a viable } \\
\text { business concept was challenging. Among } \\
\text { others, the local science park became } \\
\text { involved: 'We worked on structuring and } \\
\text { narrowing down the project, focusing on } \\
\text { product development issues and technical } \\
\text { solutions that could generate income to the } \\
\text { project, both in the short and long term. [...] } \\
\text { It was necessary to downscale the project in } \\
\text { accordance with how much funding that could } \\
\text { be possible to obtain.' (S1) } \\
\text { When some initial funding was in place, Beta } \\
\text { was able to engage a strengthened } \\
\text { management team: '[Consultant firm] is hired } \\
\text { to strengthen the management of Beta. We are } \\
\text { two researchers who will run a process where } \\
\text { we have little competency. We will go into } \\
\text { pre-clinical and clinical, and then is [N.N.] } \\
\text { the right person. We will do a business } \\
\text { development job, which is something } \\
\text { researchers cannot use the time to learn. Then } \\
\text { [N.N.] is the right person with his experience } \\
\text { from other cases. So now we feel that we as } \\
\text { researchers are complemented with very good } \\
\text { competency in the areas we do not cover.' } \\
\text { (F1) }\end{array}$ & $\begin{array}{l}\text { credibility in the university organization. } \\
\text { When the IPR was arranged and Beta formally } \\
\text { established, the next challenge was to obtain funding } \\
\text { for further development. Although some public funds } \\
\text { were available, there was also a need to get } \\
\text { investments from private sources. According to an } \\
\text { experienced professor not formally involved in Beta: } \\
\text { 'The process of raising funds was done by an } \\
\text { organization [...]. This was not a success because it } \\
\text { was not done in a clever way in my opinion. They } \\
\text { arranged a great public meeting where } 2 \text { people met } \\
\text { The problem is that there is not enough competency } \\
\text { to get funding. [...] So I told the entrepreneurs to use } \\
\text { professional people here, someone with experience } \\
\text { and who know about secrecy and such.' (O1) } \\
\text { Several actors provided assistance in the funding } \\
\text { process. Through several iterations, Beta got access } \\
\text { to the competency that subsequently led to several } \\
\text { successful rounds of private investments. According } \\
\text { to the new Chairman of the Board: '[Science park } \\
\text { innovation company] have followed this project over } \\
\text { time, so when they saw some structure and } \\
\text { competency coming into the company they were } \\
\text { involved and pushed this process. So they have both } \\
\text { contributed with funding and credibility to the } \\
\text { company.' (B2) }\end{array}$ & $\begin{array}{l}\text { difficult when fighting with others and try to } \\
\text { make things happen. When you are two, one is } \\
\text { usually up when the other is down, and there is } \\
\text { always one to pull the other up when things are } \\
\text { heavy. We have worked together for } 10 \text { years } \\
\text { and know each other well. Our motivation now } \\
\text { is that both I and [Co-founder] really want to } \\
\text { see that this project becomes something. We } \\
\text { know there is a great risk. We are used to the } \\
\text { scientific risk.' (F2) } \\
\text { The entrepreneurs continued to play a key role } \\
\text { as champions for the venture. This was greatly } \\
\text { acknowledged by the new Chairman of the } \\
\text { Board that became involved at a later stage: 'I } \\
\text { have also been very in favour of that the } \\
\text { entrepreneurs have an active role in the } \\
\text { company. As it is now with [N.N.] as CEO and } \\
\text { [N.N.] as CTO they are an excellent team which } \\
\text { have a potential to go far with this. But it is also } \\
\text { important that they get some support and } \\
\text { expertise around them. If they get some } \\
\text { keywords they are going head on and doing fine, } \\
\text { but they need some sparring partners who have } \\
\text { done this before.' (B2) }\end{array}$ \\
\hline Gamm & $\begin{array}{l}\text { The realization of the commercial potential } \\
\text { began when a senior lecturer within the school } \\
\text { of electrical engineering was discussing his } \\
\text { work with a researcher within the school of } \\
\text { human development. Together they theorized } \\
\text { that his cutting edge research into fluid flow } \\
\text { measurement could be used to develop a }\end{array}$ & $\begin{array}{l}\text { The university provided key resources to help sustain } \\
\text { the venture as the founders learnt how to better } \\
\text { address the market need. The TTO support was } \\
\text { central to this effort. 'Once [Founder 1] explained } \\
\text { what they had to me, I did my best to keep them } \\
\text { going. We paid all the patent costs and persuaded } \\
\text { the head of school to allow them to use the lab to test }\end{array}$ & $\begin{array}{l}\text { Different individuals were seen to champion the } \\
\text { venture at different stages of development, yet } \\
\text { they shared a common motivation, as explained } \\
\text { by the chairman: 'I've seen this happen so many } \\
\text { times in universities. The academic just wants } \\
\text { his research to be used, to help save lives or } \\
\text { whatever, and can't understand why everyone }\end{array}$ \\
\hline
\end{tabular}




\begin{tabular}{|c|c|c|c|}
\hline & $\begin{array}{l}\text { ground breaking medical device. They worked } \\
\text { together to develop a prototype device and } \\
\text { generated promising test results. When } \\
\text { approaching medical staff, the academics soon } \\
\text { realized that their enthusiasm was not shared: } \\
\text { 'It was so different from the current devices } \\
\text { that they were using that they couldn't } \\
\text { understand how it worked or how they could } \\
\text { use it, it was very frustrating for us. (F1) } \\
\text { Once the post doc joined the team there was a } \\
\text { step change in opportunity development. } \\
\text { Much simpler prototypes were developed that } \\
\text { were more easily understood by the medics } \\
\text { and test data was generated that showed how } \\
\text { their new device outperformed current best } \\
\text { practice. However, this took time and the seed } \\
\text { funding raised initially from public funds was } \\
\text { rapidly being consumed by patent, } \\
\text { consultancy, and regulatory fees as the Post- } \\
\text { Doc commented: '[...] The TTO were great at } \\
\text { finding money for patent costs but they had no } \\
\text { idea about the regulatory hurdles for medical } \\
\text { devices, it's a complete minefield. We were } \\
\text { really getting nowhere until we got our } \\
\text { chairman on board' (F2) }\end{array}$ & $\begin{array}{l}\text { their prototypes, during idle periods, free of charge' } \\
\text { (S1) } \\
\text { Initially the senior lecturer gave the venture } \\
\text { credibility within the school through building a } \\
\text { relationship with other researchers and the TTO. He } \\
\text { then delegated responsibility to his ex post doc to } \\
\text { reconfigure the technology to meet the need of the } \\
\text { potential customers. The team did not have the } \\
\text { competency to articulate the potential value of the } \\
\text { venture within the investment community. Only by } \\
\text { attracting an experienced entrepreneur to the team } \\
\text { did VC investment materialize. } \\
\text { 'We got our finance director, our marketing director, } \\
\text { all with contacts into the industry. In a few months } \\
\text { they wrote a new business plan and took me along to } \\
\text { pitch it to a local VC... We walked away, after a } \\
\text { few legal meetings with half a million' (F1) }\end{array}$ & $\begin{array}{l}\text { else doesn't share that passion. It took a long } \\
\text { time to convince him that we did want to save } \\
\text { lives, but that we have to spend a lot more time } \\
\text { showing how it is going to make money than } \\
\text { how it is going to save lives to get anything } \\
\text { done' (B1) } \\
\text { This pragmatic view is echoed by the TTO: 'It's } \\
\text { great that we finally got the kit made and it's } \\
\text { now being used in hospitals. It's even better that } \\
\text { [Senior lecturer] is taking business school } \\
\text { courses and now wants to take his other } \\
\text { research forward. I think the process will be less } \\
\text { painful the second time around' (S1) }\end{array}$ \\
\hline Delta & $\begin{array}{l}\text { Delta arose from the research work of two } \\
\text { professors within the school of civil } \\
\text { engineering. They were both interested in } \\
\text { environmental issues and their research } \\
\text { uncovered a possible method to increase the } \\
\text { energy efficiency of air conditioning units. } \\
\text { They developed a bench top model but were } \\
\text { uncertain how to take this forward to illustrate } \\
\text { the potential benefits to customers. 'We knew } \\
\text { we were onto something but we were both } \\
\text { career academics, we didn't know how to } \\
\text { engage with industry and sell them the idea. }\end{array}$ & $\begin{array}{l}\text { The post doc who joined the team was able to work } \\
\text { full time on bringing in resources to develop the } \\
\text { opportunity further. He was active in building } \\
\text { relationships with the TTO to help patent the } \\
\text { technology, which ultimately led to securing a } \\
\text { development partner. 'To attract potential partners } \\
\text { the IP office suggested we make some commercial in } \\
\text { confidence flyers. We disseminated these everywhere } \\
\text { we could think of. We said nothing about how it } \\
\text { works. We sent it to businesses that may be } \\
\text { interested detailing the applications and outlining } \\
\text { the benefits. Six firms of differing sizes came to visit }\end{array}$ & $\begin{array}{l}\text { The two research professors were consistent } \\
\text { champions for their technology for the ten years } \\
\text { of development effort. A step change was } \\
\text { observed once the post doc joined the team. } \\
\text { Following the proof of concept period, he } \\
\text { subsequently gained a fellowship to learn how to } \\
\text { commercialize university based research. As a } \\
\text { consequence of the fellowship he was } \\
\text { introduced to networks of TTOs, industrialists, } \\
\text { and potential investors, with the latter two } \\
\text { groups investing in the technology once it was } \\
\text { shown to have commercial viability in }\end{array}$ \\
\hline
\end{tabular}




\begin{tabular}{|c|c|c|c|}
\hline & $\begin{array}{l}\text { Once we got the young post doc on board he } \\
\text { went out and looked at what was out there, } \\
\text { started us thinking about what was better } \\
\text { about our device. We soon realized that } \\
\text { cheaper running costs was how to sell it to } \\
\text { potential partners' (F1) } \\
\text { The Delta professors applied for a small grant } \\
\text { to help develop the proof of concept. This } \\
\text { provided a post doc researcher for six months } \\
\text { who wasted no time in establishing the market } \\
\text { value of the invention. } \\
\text { The post doc worked full time with potential } \\
\text { customers to establish the comparative } \\
\text { advantage of this technology relative to } \\
\text { current offerings and then modifying the } \\
\text { technology to meet the expectations of the } \\
\text { market. }\end{array}$ & $\begin{array}{l}\text { us and signed confidentiality agreements. We had a } \\
\text { dialogue with a number and then one came on board } \\
\text { as development partners. They have been absolutely } \\
\text { fantastic.' (F2) } \\
\text { The post doc helped to develop the business plan for } \\
\text { the nascent venture. This plan was honed and } \\
\text { developed through entry in business plan } \\
\text { competitions and through close working with their } \\
\text { new industry partners. 'Our partners entered the } \\
\text { concept into two business competitions. We came } \\
\text { second in one and gained a lot of publicity. [...] It } \\
\text { also gave independent validation of the technology.' } \\
\text { (T1) } \\
\text { Once the test results generated by the partnership } \\
\text { proved positive, the partner firm moved forwards } \\
\text { quickly and released more funding for the co- } \\
\text { development of a new generation of products } \\
\text { utilizing the new technology. }\end{array}$ & $\begin{array}{l}\text { conjunction with their industry partner. The } \\
\text { original professors were motivated by ideology } \\
\text { rather than commercial drivers. 'It is a long hard } \\
\text { road from academe to commercialisation. You } \\
\text { need larger tranches of money to bridge the gap. } \\
\text { We started in 1999. [...] We stuck to it because } \\
\text { of our belief in the technology and dogged } \\
\text { determination to produce something that would } \\
\text { save energy and combat global warming.' (F2) } \\
\text { The post doc's role grew as the development } \\
\text { progressed and he became research manager of } \\
\text { product development within the joint venture. } \\
\text { This rapid career progression was a surprise to } \\
\text { the post doc: 'I took the proof of concept work } \\
\text { as I really didn't want to stay in the lab, but } \\
\text { didn't know what else to do. Once the kit started } \\
\text { working well I applied for the fellowship } \\
\text { because I realized this is what I really wanted to } \\
\text { do. I think that this is where my talent lies, not } \\
\text { just working in the lab but trying to take } \\
\text { research out of the lab and turn it into new } \\
\text { products.' (T1) }\end{array}$ \\
\hline
\end{tabular}


Table V. Characteristics of the competencies summarized

\begin{tabular}{|c|c|c|c|c|}
\hline & & Opportunity refinement & Leveraging & Championing \\
\hline \multirow[t]{4}{*}{$\begin{array}{l}\text { Case } \\
\text { specific } \\
\text { details }\end{array}$} & Alpha & $\begin{array}{l}\text { Idea identified from industry } \\
\text { experience and refined in iterative } \\
\text { process with industry. }\end{array}$ & $\begin{array}{l}\text { Deliberate team composition with strong } \\
\text { industry alliances and legitimacy towards } \\
\text { resource providers. }\end{array}$ & $\begin{array}{l}\text { Motivated inventors with capacity and } \\
\text { ability to engage support from others. }\end{array}$ \\
\hline & Beta & $\begin{array}{l}\text { Inventors learn about business. Support } \\
\text { actors and new team members help } \\
\text { framing the idea. }\end{array}$ & $\begin{array}{l}\text { Strong university support. Iteration to be } \\
\text { able to gain external investment. }\end{array}$ & $\begin{array}{l}\text { Inventors with high motivation to } \\
\text { succeed. Were able to attract team } \\
\text { members with complementary expertise. }\end{array}$ \\
\hline & Gamma & $\begin{array}{l}\text { Effort needed to communicate the idea } \\
\text { to industry. Iteration to meet industry } \\
\text { requirements. }\end{array}$ & $\begin{array}{l}\text { Initial support from TTO. Experienced } \\
\text { entrepreneur framed and legitimized the } \\
\text { business model. }\end{array}$ & $\begin{array}{l}\text { Motivated inventor. New team members } \\
\text { joined to develop idea and business } \\
\text { model. }\end{array}$ \\
\hline & Delta & $\begin{array}{l}\text { Idea framed by active iteration with } \\
\text { market. }\end{array}$ & $\begin{array}{l}\text { Initial support from TTO. New } \\
\text { development partner provided business } \\
\text { knowledge. }\end{array}$ & $\begin{array}{l}\text { Inventors believed in the technology. Post } \\
\text { doc enjoyed being an entrepreneur. }\end{array}$ \\
\hline \multirow{2}{*}{$\begin{array}{l}\text { Cross- } \\
\text { case } \\
\text { common- } \\
\text { alities }\end{array}$} & $\begin{array}{l}\text { Competency } \\
\text { role }\end{array}$ & $\begin{array}{l}\text { Opportunity recognition and further } \\
\text { exploitation of the opportunity. }\end{array}$ & $\begin{array}{l}\text { Accessing and combining new sources of } \\
\text { resources (tangible and intangible). }\end{array}$ & $\begin{array}{l}\text { Identifying with the opportunity and take } \\
\text { responsibility of moving it forward. }\end{array}$ \\
\hline & $\begin{array}{l}\text { Key tasks } \\
\text { throughout } \\
\text { process }\end{array}$ & $\begin{array}{l}\text { Initial technology and market } \\
\text { development and subsequent adaptation } \\
\text { and refinement of the business concept. }\end{array}$ & $\begin{array}{l}\text { Initial institutional positioning and } \\
\text { gradually more focus on external } \\
\text { contacts. }\end{array}$ & $\begin{array}{l}\text { Initial entrepreneurial drive and gradually } \\
\text { more professional management. }\end{array}$ \\
\hline
\end{tabular}

